\title{
Pomoc i współpraca w czasie pandemii. Zarys problemu
}

\section{Abstract \\ Help and Cooperation during a Pandemic Time. Outline of the Problem}

The article presents the results of research, the axis of which were help initiatives taken during the COVID-19 pandemic. A characteristic feature, and previously unheard of on such a scale, is the initiation, and often full implementation of these activities in the virtual world. The time of the pandemic has blurred the clarity of the categories of those most affected or most in need of help in the events that took place. Another feature of the observed events is their phased. Its elements are spontaneously emerging groups that undertake aid actions. Restoring the "state of normality" and taking over the aid activities by institutions established for this slowed down and weakened the participation of ordinary people in organizing spontaneous activities. The time lived has the features of Turner's liminality, and assistance groups can be described by the term Communitas.

Keywords: help initiatives, COVID-19 pandemic, spontaneously emerging groups, communitas, new normality, liminality

Klęski żywiołowe zawsze stanowiły realne zagrożenie dla bytu zarówno poszczególnych osób, jak i całych społeczności. Doskonałym odzwierciedleniem wzbudzanego przez nie strachu są słowa Suplikacji, pieśni o charakterze błagalnym: „Od powietrza, głodu, ognia i wojny wybaw nas Panie!”. Epidemie i inne klęski, jak na przykład zarazy roślin, anomalie pogodowe (powodujące np. powodzie), ogień wywołany czy to zjawiskami natury, czy też działaniami ludzi, a w końcu głód, zazwyczaj następujący po wszystkich wymienionych zdarzeniach, były tymi stanami, które wzbudzały największe obawy. 
Postęp cywilizacyjny, a przede wszystkim wiedzy medycznej sprawił, że większość Europejczyków, w tym Polaków, żyła w przeświadczeniu, iż epidemie i zarazy to przeszłość, a sytuacje znane z kart historii nie wrócą do naszej rzeczywistości. Wydawało się, że zamożne społeczności Europy czy Ameryki Północnej mają wiedzę i „narzędzia” do zwalczania „w zalążku” problemów epidemicznych. Poczucie bezpiecznego życia warunkowanego poziomem rozwoju cywilizacyjnego okazało się złudne. Należałoby stwierdzić, że było niezasadnie optymistyczne. Wystarczy bowiem sięgnąć do przeszłości zaledwie nieco wykraczającej ponad 100 lat, a „dotkniemy” czasów wysoce śmiertelnej grypy hiszpanki. Patrząc na krótki fragment dziejów przełomu XX i XXI w., nawet tylko z perspektywy Polski, zobaczymy cyklicznie powtarzające się co parę lat klęski żywiołowe - powodzie ${ }^{1}$, trąby powietrzne ${ }^{2}$ czy katastrofalne osuwiska ${ }^{3}$. W tym czasie pojawiały się także informacje o epidemiach, które jednak działy się „gdzieś indziej”, nie dotykając nadto „naszego świata”.

Rok 2020 przyniósł wydarzenia, których przeciętny Polak, czy szerzej - Europejczyk, nie spodziewał się. Mowa oczywiście o COVID-19. Przyczyn szybkiego rozprzestrzeniania się choroby upatruje się w podróżach turystycznych, służbowych i prywatnych zamożnych Europejczyków oraz mieszkańców Ameryki Północnej, które sprawily, że szybko wirus SARS-CoV-2 zaistniał praktycznie we wszystkich zakątkach Ziemi. Gwałtownie rozwijająca się na całym świecie epidemia ${ }^{5}$ spowodowała bezprecedensowe działania rządów poszczególnych państw, prowadzące do ograniczenia różnych form życia społecznego i gospodarczego. Dawne metody izolacji wydawały się w początkowym etapie epidemii jedyną skuteczną metodą zapanowania nad nią. Zamknięto szkoły, urzędy, teatry, kina, muzea i inne instytucje kultury, a także kościoły. Terminem nadrzędnym, który

1 Przypomnę powódź z 1997 r. nazwaną powodzią tysiąclecia, także kolejne w latach: 1998, 2001, 2008, 2010, 2013, 2018. Cf. https://pl.wikipedia.org/wiki/Pow\%C3\%B3d\%C5\%BA (dostęp: 12.08.2020); M. Żukow-Karczewski, Największe powodzie na świecie - przyczyny, skutki i zdjęcia, https://www.ekologia.pl/srodowisko/ochrona-srodowiska/najwieksze-powodzie-na-swiecieprzyczyny-skutki-i-zdjecia,16628.html (dostęp: 12.08.2020).

2 Europejska Baza Danych o Gwałtownych Zjawiskach Atmosferycznych (European Severe Weather Database: https://eswd.eu/cgi-bin/eswd.cgi) zawiera dane dotyczące 358 zdarzeń typu tornado/trąba powietrzna na terenie Polski w okresie 01.01.2000-10.08.2020. Za okres 01.01.202010.08.2020 w Polsce odnotowano 7 takich zdarzeń (dostęp: 11.08.2020 za pośrednictwem strony: https://lowcyburz.pl/eswd/).

3 Po powodzi w 2010 r. odnotowano 1300 osuwisk, które objęły nie tylko użytki rolne, ale także domostwa, co spowodowało konieczność ewakuacji około 5000 osób, http://www.rp.pl/ artykul/488738-Ponad-1300-osuwisk-w-Malopolsce.html; strona zarchiwizowana na: https:// archive.is/TbpfE (dostęp: 12.08.2020).

4 Epidemie SARS 2002-2003, ptasiej grypy 2003-2006, świńskiej grypy 2009-2010, Eboli 20132016, https://www.medonet.pl/koronawirus/to-musisz-wiedziec,najwieksze-epidemie-ostatnich- lat-koronawirus--sars--ptasia-grypa--ebola,artykul,15776010.html (dostęp: 25.08.2020).

5 Co spowodowało ogłoszenie przez WHO z dniem 11.03 .2020 r. stanu pandemii. Cf. https:// pulsmedycyny.pl/who-oglosilo-pandemie-covid-19-co-to-oznacza-984790 (dostęp: 12.08.2020). 
określał zasady życia większości Europejczyków w tym czasie - stał się tzw. lockdown. Zaczęły obowiązywać zakazy opuszczania domów, przemieszczania się bez „wyraźnej” potrzeby, nakazy utrzymywania „dystansu społecznego” (również w stosunku do rodziny mieszkającej w innym miejscu), osłaniania ust i nosa. Opustoszały ulice, centra miast, większość sklepów w galeriach handlowych została zamknięta. W sklepach spożywczo-przemysłowych towary spożywcze o długich terminach ważności (takie jak makarony, kasza, ryż, herbata, kawa, cukier) były wykupywane. Podobnie było z produktami masarniczymi (możliwymi do zamrożenia) i towarami gospodarstwa domowego (papier toaletowy, proszek do prania, itp.). Wszystko to sygnalizowało przygotowywanie zapasów „na czarną godzinę”.

Okoliczności z początku 2020 r. sprawiły, że zaczęłam obserwować „zdalnie” (gdyż izolacja społeczna objęła także mnie) zachodzące wydarzenia i podejmowane działania pomocowe. Zastanawiałam się, w jakim stopniu są one podobne do tych podejmowanych w sytuacjach wspomnianych klęsk żywiołowych, takich jak powodzie, trąby powietrzne czy osuwiska. Oczywiście, można dostrzec różnice w sytuacji epidemii i innych klęsk żywiołowych. Przede wszystkim zasięg społeczny obserwowanych w 2020 r. zjawisk, a także nakazy i zakazy władz okazały się zdecydowanie bardziej restrykcyjne. Powodowały one wiele utrudnień w codziennym życiu i były doświadczane praktycznie przez całe społeczeństwo. Trudno jednakże zestawiać i „ważyć” tragedie przeżywane przez poszczególne osoby czy rodziny w sytuacji „zwykłych” klęsk żywiołowych (związane z utratą dorobku życia - niekiedy kilku pokoleń; miejsca życia; domostwa; źródeł utrzymania; utraty zdrowia; ryzyka śmierci) i lęk przed nieznaną chorobą oraz związanym z nią ryzykiem zakażenia i śmierci. Przedłużający się czas wprowadzonych ograniczeń, uniemożliwiający „normalne” funkcjonowanie zarówno pojedynczych osób, jak i całego społeczeństwa, wywołał nowe obawy o stabilność zawodową, o zachowanie pracy, dotychczasowej pozycji materialnej i statusu społecznego. Przeżyte traumatyczne wydarzenia niewątpliwie pozostawiają ślad w życiu indywidualnym i społecznym ${ }^{6}$. Jaki będzie on w przypadku COVID-19, trudno wyrokować, wziąwszy pod uwagę, że w chwili gdy piszę te słowa (30.08.2020), pandemia nadal trwa. To, co już można zauważyć i na co chciałabym dalej zwrócić uwagę, to zaobserwowana, m.in. w kontekście działań pomocowych, etapowość obserwowanego zjawiska.

W obrębie moich zainteresowań przede wszystkim pozostawały podejmowane działania pomocowe i związane z nimi różne formy współdziałania. Zagadnie-

6 Po tzw. powodzi tysiąclecia z 1997 r. powstało wiele prac poświęconych społecznościom, które przeżyły traumę wywołaną klęskami żywiołowymi (cf. Sołdra-Gwiżdż 1998; Kaniasty 2003; Hajduk-Nijakowska 2005; Baniowska-Kopacz 2017). Piotr Sztompka zaznaczył natomiast, że trauma w wymiarze społecznym „to zjawisko zbiorowe, stan odczuwany przez całą grupę, społeczność w wyniku zdarzeń destabilizujących” (Sztompka 2000: 27). 
nia te od dawna nurtują badaczy analizujących je w ramach teorii wymiany ${ }^{7}$, której jednym z najważniejszych elementów jest zasada wzajemności. Znajduje ona realizację zarówno w interakcjach zachodzących pomiędzy jednostkami, jak i jednostką a społecznością.

Marcel Mauss uważał, że uczestnicy wymiany (pojedyncze osoby, rodziny, grupy) dążą nie tyle do wzbogacenia się, ile do zwiększenia swojego prestiżu i utrwalenia więzi już istniejących bądź też do zawarcia nowych. Uważał, że wymianę należy rozpatrywać jako „świadczenie całościowe” (całościowy fakt społeczny, Mauss 1973; cf. Lévi-Strauss 1973: XXIX-XXX). Podstawą tak realizowanej wymiany jest obowiązek „dawania, przyjmowania i odwzajemniania” darów. Teoria Maussa dotyczy nie tylko wymiany dóbr materialnych, lecz także wszystkiego, czemu dana grupa przypisuje wartość. To działanie, które - przynajmniej okresowo - angażuje i skupia wokół siebie całość życia społecznego danej zbiorowości. Bronisław Malinowski w kontekście zagadnienia wymiany zwraca szczególną uwagę na zasadę wzajemności (Malinowski 1967, 1984), uznając ją za podstawę równowagi i porządku w życiu społecznym. Wymiana świadczeń, usług, darów łączy - jego zdaniem - partnerów wymiany w sposób trwały, dając w ten sposób podstawy do kształtowania się praw i reguł postępowania. Uważa, że zachowania, które są regulowane przez zasadę wzajemności, podlegają nakazowi utrzymywania równowagi świadczeń (reguła symetrii; Malinowski 1984: 17-54). Claude Lévi-Strauss uogólnił koncepcję Maussa, czyniąc z niej podstawę dla swojej teorii stosunków pokrewieństwa. Istotne dla moich rozważań jest to, że - jak podkreśla Lévi-Strauss - wymiana zachowuje charakter całościowego faktu społecznego nie tylko w tzw. społecznościach prymitywnych (na których przykładzie ją opisano), lecz także w „naszych” społeczeństwach (Lévi-Strauss 1970). Alwin Gouldner, definiując zasadę wzajemności, zaznaczył, że zobowiązuje ona człowieka do działania na rzecz innych ludzi przez wzgląd na ich wcześniejsze działania wobec niego, nie zaś przez wzgląd na ich społeczne cechy i pozycje (Gouldner 1992: 91). Znaczenie emocjonalnych/afektywnych pobudek dla podejmowanych tego typu działań podkreślają psycholodzy społeczni. Najpełniejszy wydźwięk znalazła ona w koncepcji empatii i altruizmu. W jej ujęciu zachowania pomocowe, określane także jako prospołeczne, są postrzegane jako akty czysto altruistyczne, motywowane empatią i współczuciem (Aronson, Wilson, Akert 1997: 429). Przeciwnicy tej koncepcji wysuwają, że nie istnieje czysty altruizm. Alwin Gouldner, akceptując to twierdzenie, zwraca jednak uwagę, że dzięki wzajemności możliwe jest istnienie „altruizmu w egoizmie”, bowiem egoizm może motywować jedną stronę do zaspokojenia oczekiwań drugiej, skłaniając ją w ten sposób do „odwzajem-

7 Dokonuję tu subiektywnego wyboru Marcela Maussa (1973), Bronisława Malinowskiego (1967; 1984), Claude’a Lévi-Straussa (1970), Alwina Gouldnera (1992), Marshalla Sahlinsa (1992), Petera Blaua (1992), których koncepcje uważam za szczególnie adekwatne do analizowanej problematyki. 
nienia i zaspokojenia własnych potrzeb" (Gouldner 1992: 97). Już w tym miejscu można zaznaczyć, że w badanych sytuacjach ujawnia się aspekt spodziewanej „odroczonej wdzięczności” (Blau 1992: 265), którą można także opisać jako odroczoną formę pomocy, będącej rewanżem za wcześniej wyświadczoną przysługę. Mechanizm ten dotyczy zarówno działań pomiędzy jednostkami, jak i jednostką a grupą społeczną.

Przedstawiony powyżej zarys ram teoretycznych nie wyczerpuje tematu. Pragnę jednak zaznaczyć, że moim celem jest przede wszystkim prezentacja działań pomocowych podejmowanych w określonym czasie - od początku pandemii (w warunkach Polski to początek marca ${ }^{8}$ ) do 30 sierpnia 2020 r. To więc czas określany jako pierwsza fala COVID-19. Gdy piszę artykuł i kończę go na tym etapie, towarzyszy mi świadomość, że to proces, który trwa i który się zmienia. Dlatego, wskazując możliwe ścieżki interpretacyjne, nie dążę do „zamknięcia tematu" i wysnuwania ostatecznych wniosków. W moim odczuciu byłoby to przedwczesne.

Lockdown i izolacja społeczna uniemożliwiły organizowanie spektakularnych przedsięwzięć plenerowych, takich jak np. dobroczynne koncerty, $\mathrm{z}$ których dochód był przeznaczany na pomoc poszkodowanym $\mathrm{w}$ wyniku klęsk żywiołowych. Wobec niemożności lokowania działań pomocowych w „realnym”, trójwymiarowym świecie, wiele $\mathrm{z}$ nich zostało przeniesionych do wirtualnej przestrzeni ${ }^{9}$. Czas pandemii ujawnił nieoczywistość tego, kto najbardziej potrzebuje wsparcia w tym trudnym czasie. O ile adresaci pomocy klęsk żywiołowych na ogół nie budzą wątpliwości (to bowiem osoby, które ucierpiały wskutek zaistnienia jakiegoś żywiołu), o tyle stan epidemii zachwiał tą oczywistością. Bieg wydarzeń ostatnich miesięcy rozmył jasność kategorii osób najbardziej poszkodowanych czy najbardziej potrzebujących pomocy w dziejących się zdarzeniach. Adresaci organizowanych działań pomocowych są refleksem/odbiciem/odzwierciedleniem tej sytuacji.

Najintensywniejsze działania pomocowe nastąpiły w czasie „zamknięcia”, a więc w czasie kwarantanny społecznej. Bezpośrednie kontakty i badania terenowe w klasycznym rozumieniu nie mogły być w tym czasie realizowane. Moje badania były zatem prowadzone w wirtualnym świecie, który okazał się bardzo skuteczny w organizowanych akcjach pomocy.

Świat on-line w coraz większym stopniu staje się „drugą", „równoległą” rzeczywistością podlegającą badaniom etnograficznym. Powstało wiele prac oma-

8 Dokładniej od 4 marca, czyli podania informacji o pacjencie „0”.

9 Nie jest to nowa forma pomocy ( $c f$. Pomieciński 2012), natomiast jej zakres zdecydowanie zwiększył swój zasięg. Wirtualna przestrzeń w czasie „zamknięcia” stała się realną przestrzenią życia, w której rozmawialiśmy z najbliższymi, robiliśmy zakupy, załatwialiśmy urzędowe sprawy, pracowaliśmy, a także uczestniczyliśmy w różnych przedsięwzięciach społecznych, takich jak np. badane działania pomocowe. 
wiających problematykę prowadzonych w tym środowisku badań. Wskazują one na ograniczenia, zalety i zagrożenia procesu badawczego, wynikające zarówno ze specyfiki terenu badań, jak i stosowanej metodologii. W tym miejscu zwrócę uwagę na te, które uznaję za najistotniejsze w kontekście przeprowadzonych prac.

Przede wszystkim moje badania nie były planowane, tak jak nie była planowana pandemia COVID-19. Zaznaczam ten fakt, ponieważ częstą techniką stosowaną przez badaczy internetowych i planowaną już na etapie wstępnym jest triangulacja, czyli łączenie różnych metod w procesie badawczym (np. obejmującym zbieranie danych on-line i ich weryfikowanie w realnym świecie w sposób „klasyczny”). W przypadku moich prac zarówno sytuacja kwarantanny społecznej, jak i moja osobista $w$ tym czasie uniemożliwiły mi weryfikację poprzez spotkanie i rozmowę z osobami uczestniczącymi w prezentowanych dalej akcjach pomocy. Fakt ten pozbawił mnie możliwości obserwacji zachowań niewerbalnych, które mimowolnie ukazują (także z perspektywy czasu i aktualnej sytuacji) np. stosunek do opisywanych zdarzeń (to jeden z poważniejszych mankamentów badań on-line). Warto również zaznaczyć, że rozległość geograficzna zjawiska, które rejestrowałam ${ }^{10}$, praktycznie uniemożliwia weryfikację prac realizowanych ad hoc. Równocześnie należy podkreślić, że pokonanie bariery geograficznej, czyli możliwość niemalże synchronicznego pozyskiwania danych z miejsc bardzo odległych, należy uznać za zaletę badań internetowych. Pozwoliło to na uchwycenie powtarzalności działań ukierunkowanych na określony cel, tzn. na pospolitość (w dobrym znaczeniu tego słowa) obserwowanego zjawiska. W planowanych badaniach prowadzonych $\mathrm{w}$ „normalnym” czasie optymalną procedurą byłoby poddanie pozyskanych materiałów weryfikacji za pomocą technik, które mogą być postrzegane jako klasyczne (wywiad, obserwacja). Ze względu na wspominane ograniczenia informacje zebrane na różnych portalach informacyjnych, społecznościowych, a także zasłyszane od bliższych i dalszych znajomych sprawdzałam, poszukując ich odzwierciedlenia w oficjalnych komunikatach różnych instytucji lokalnych i ogólnokrajowych ${ }^{11}$. Gdy było to możliwe, pozyskiwałam dodatkowe informacje drogą rozmów telefonicznych ${ }^{12}$.

Pragnę jeszcze odnieść się do kwestii etycznych związanych z korzystaniem $\mathrm{z}$ treści zastanych $\mathrm{w}$ Internecie ${ }^{13}$. Różnice $\mathrm{w}$ stanowiskach badaczy w odniesieniu

10 Prosiłam także moich znajomych z różnych części Polski i Europy o zbieranie oraz przesyłanie interesujących mnie danych. Materiały spoza Polski nie są prezentowane w artykule, jednakże pomogły mi spojrzeć na obserwowane zjawiska w szerszym kontekście. Uczestnikom tych badań Dorocie Halbiniak-Mutikainen, Marcie i Joanie Hughes, Andrzejowi Patoniowi i Piotrowi Świątkowskiemu - serdecznie dziękuję za pomoc w zbieraniu materiałów.

11 Zarchiwizowano 176 linków dotyczących różnych form pomocy.

12 Rozmowy te nie były rejestrowane, a w przypadku powoływania się na nie w artykule zaznaczam „archiwum autorki”.

13 Były to przede wszystkim dane z oficjalnych portali rządowych i ich lokalnych odpowiedników, artykuły, reportaże (najczęściej ukazujące lokalne działania pomocowe), portale społecz- 
do tych zagadnień wynikają z dualistycznego charakteru sieci (także serwerów publicznych), łączącego, przenikającego, w różnych kombinacjach i z różnym naciskiem to, co należy do sfery publicznej i prywatnej (cf. Batorski, Olcoń-Kubicka 2006: 124-125). Osobiście przychylam się do stanowiska, że treści (w tym np. wypowiedzi na forach internetowych) dostępne na stronach ogólnodostępnych mogą być przedmiotem badań $\mathrm{z}$ możliwością ich publikacji w pracach naukowych. Natomiast szczególnej ochronie (szyfrowaniu) powinny podlegać wypowiedzi prywatne, a także te, które zostały usunięte lub pochodzą z zamkniętych forów dyskusyjnych ( $c f$. Jemielniak 2013, s. 109).

\section{Adresaci pomocy i działania pomocowe}

Jak już zasygnalizowałam powyżej, działania pomocowe najpełniej rozwinęły się w czasie „zamknięcia” (lockdown). Były one najczęściej realizacjami spontanicznymi, oddolnymi i nakierowanymi na pomoc ludziom, których można ująć w dwie grupy. Pierwsza to osoby, które zostały objęte obowiązkiem odbycia kwarantanny oraz te, które wskutek osobistej sytuacji życiowej (np. zaawansowany wiek, występowanie tzw. chorób współistniejących, niezaradność lub inne okoliczności) nie dawały sobie rady z podstawowymi codziennymi czynnościami. Drugą grupę stanowią pracownicy ochrony zdrowia (lekarze, pielęgniarki, sanitariusze, ratownicy medyczni, a także laboranci i inne osoby z tzw. personelu pomocniczego placówek ochrony zdrowia), którzy $\mathrm{z}$ dnia na dzień, często bez wyposażenia w odzież ochronną, musieli nadal pełnić swoje obowiązki z narażeniem zdrowia i życia ${ }^{14}$.

\section{Osoby objęte kwarantanną, ich rodziny i działania pomocowe}

Obowiązek odbycia kwarantanny zarówno przez osobę, u której zdiagnozowano wirusa, jak i przez wszystkie osoby z nią zamieszkujące skutkował zakazem opuszczania domu, także w celu zaspokojenia nawet najbardziej elementarnych potrzeb, takich jak uzupełnienie żywności czy zakup leków. Zakaz ten niejednokrotnie obejmował również szerszą rodzinę (niezamieszkałą z osobą zarażoną),

nościowe (Facebook, Instagram), fora dyskusyjne oraz oficjalne strony poszczególnych organizacji i fundacji organizujących zbiórki pieniędzy na pomoc w walce z COVID-19.

14 Na dzień 03.06.2020 zarażonych medyków w związku z epidemią wg szacunków Ministerstwa Zdrowia było 24545 , co stanowiło 9,79\% wszystkich zakażonych w tym dniu, https://konkret24.tvn24.pl/zdrowie,110/2-4-tys-pracownikow-medycznych-w-polsce-zostalo-zakazonych-koronawirusem,1018742.html (dostęp: 24.08.2020). 
a także najbliższych znajomych, z którymi chory przed diagnozą utrzymywał codzienne kontakty ${ }^{15}$. W podobnej sytuacji znalazły się też inne osoby (np. wracające z podróży zagranicznych), które wskutek wprowadzonego stanu zagrożenia epidemicznego (od 14.03.2020) ${ }^{16}$, a następnie stanu epidemii (od 20.03.2020) ${ }^{17}$ musiały poddać się obowiązkowej dwutygodniowej kwarantannie. Działania pomocowe kierowano także do seniorów i innych osób, zwłaszcza samotnych, które np. z powodu chorób tzw. towarzyszących znalazły się w grupie wysokiego ryzyka ciężkiego przebiegu COVID-19. Pojawiające się komunikaty wyraźnie zalecały im pozostawanie $\mathrm{w}$ domu ${ }^{18}$. Uwarunkowania, $\mathrm{w}$ jakich znalazły się wymienione grupy ludzi, spowodowały oczywiste komplikacje w codziennym życiu. Dlatego też te osoby stały się jednymi z pierwszych adresatów pomocy.

W podejmowanych przez władze działaniach wprawdzie nie zapomniano o potrzebach dnia codziennego ludzi odbywających kwarantannę, jednakże włączenie nowych form pomocy $\mathrm{w}$ zakres obowiązków instytucji powołanych do działań socjalnych (np. MOPS-u) wymagało sporo czasu ${ }^{19}$. Właśnie w tym pierwszym okresie wsparcia udzielały osoby z najbliższego sąsiedztwa ${ }^{20}$. Było to najwyraźniej widoczne w mniejszych społecznościach, charakteryzujących się większą spójnością wewnętrzną, wiedzą o sytuacji rodzinnej i potrzebach członków danej społeczności. W warunkach dużych miast funkcję koordynatorów i pośredników pełniły często lokalne wspólnoty parafialne ${ }^{21}$, a także inne organizacje działające na określonym terenie ${ }^{22}$. Wiedza o potrzebujących wsparcia była najczęściej prze-

15 W ciągu dwóch tygodni od stwierdzenia zarażenia informacje na ten temat podawały wszystkie media, w tym także serwisy internetowe, https://www.medonet.pl/koronawirus/ poradnik,jak-wyglada-kwarantanna-domowa-przy-podejrzeniu-koronawirusa--lista-zasad-ktorych-trzeba-przestrzegac,artykul,47203195.html (dostęp: 25.03.2020).

16 https://rcb.gov.pl/stan-zagrozenia-epidemicznego/ (dostęp: 15.03.2020).

17 https://www.gov.pl/web/koronawirus/wprowadzamy-stan-epidemii-w-polsce (dostęp: 25.03.2020).

18 Taka też była idea wprowadzenia godzin zakupów tylko dla seniorów.

19 Było to związane z pozostaniem w domach wielu pracowników tych instytucji celem opieki nad dziećmi (wskutek zamknięcia szkół i przedszkoli jedno z rodziców miało możliwość pozostania $\mathrm{w}$ domu), co powodowało kłopoty kadrowe.

$20 \quad 16.03 .2020$, na Onecie opublikowano felieton prezentujący zachowania $\mathrm{w}$ nowej rzeczywistości: https://kobieta.onet.pl/koronawirus-w-polsce-pokazuje-ze-nie-taki-polak-strasznyjak-go-maluja/zgd8fbh (dostęp: 11.04.2020).

21 Powstające spontanicznie akcje pomocy w późniejszym etapie zyskały formę już bardziej zorganizowaną, przykładem może być akcja „Wspólnoty pomocy”, oparta na wspólnotach parafialnych: https://wspolnotypomocy.pl/o-akcji/ (dostęp: 08.04.2020).

22 Przykładem może być akcja instruktorów harcerskich (osób pełnoletnich), które dostarczały konieczne produkty lub pomagały $\mathrm{w}$ innych codziennych sprawach zarówno osobom starszym, jak i pozostającym w izolacji, https://zhp.pl/2020/harcerska-sluzba-ma-wiele-wymiarow/; https:// www.krakow.pl/aktualnosci/238590,34,komunikat,harcerze_czuwaja_w_czasie_epidemii.html?_ ga=2.181738977.71523184.1585309445-1708338192.1582880751 (dostęp: 01.04.2020); http:// 
kazywana przez znajomych, co tworzyło niejednokrotnie łańcuszek powiązań pomiędzy osobą pomagającą i odbiorcą pomocy.

Uzupełnianie produktów spożywczych, zakup leków, wyprowadzenie na spacer psa czy wyrzucenie śmieci, a także opłacenie comiesięcznych rachunków wszystkie te sprawy były głównymi polami podejmowanych działań. Kontakt pomagający-adresat pomocy najczęściej nie był bezpośredni (np. zakupy pozostawiano przed drzwiami wejściowymi do domu). W późniejszym czasie wymienione formy pomocy były przejmowane i koordynowane przez przedstawicieli lokalnych władz i służb, np. MOPS, straż miejską, ochotniczą straż pożarną, a czasem policję. Ponieważ informacje o organizowanej pomocy były podawane na stronach internetowych ${ }^{23}$, wciąż bardzo ważną rolę odgrywały osoby z bliskiego sąsiedztwa, które pośredniczyły w nawiązywaniu kontaktów między potrzebującym wsparcia a instytucją. Nadal także korzystano z udziału w działaniach pomocowych osób formalnie niezwiązanych z daną agendą.

Wraz z trwaniem epidemii pojawiały się nowe potrzeby i sposoby okazywanego wsparcia. Poczucie utraty samodzielności w codziennym życiu, potęgowane przez przedłużającą się izolację, a także podawane do publicznej wiadomości „apokaliptyczne” informacje bardzo szybko ujawniły rodzące się - zwłaszcza wśród osób starszych i chorych - stany przygnębienia ${ }^{24}$. W tej sytuacji rozmowa telefoniczna, w czasie której omawiano potrzeby danej osoby, bardzo często przeradzała się w swobodną pogawędkę, stającą się namiastką „wyjścia z domu” i spotkania $z$ drugim człowiekiem ${ }^{25}$. Innymi formami wsparcia były oferowanie opieki nad dziećmi czy pomoc w nauczaniu zdalnym.

Wraz z wprowadzeniem obowiązku zasłaniania nosa i ust (od 16.04.2020) ${ }^{26}$ powstała nowa przestrzeń koniecznej pomocy. Wobec braku w aptekach i innych punktach sprzedaży jakichkolwiek maseczek ochronnych rozwinął się spontaniczny ruch ich szycia celem zaspokojenia potrzeb nie tylko swojej rodziny, lecz także

perspektywy.pl/portal/index.php?option $=$ com_content\&view $=$ article\&id $=4554$ :dorosli-harcerzez-zhp-na-sluzbie-w-zwiazku-z-epidemia-covid-19\&catid=24\&Itemid=119 (dostęp: 01.04.2020).

${ }_{23} \mathrm{Na}$ przykład: https://www.krakow.pl/aktualnosci/238188,2116,komunikat,jak_zglosic_ potrzebe_pomocy_w_zwiazku_z_kwarantanna_.html (dostęp: 11.04.2020).

24 Były one powodowane nie tyle obawą o siebie, ile o bezpieczeństwo dzieci i wnuków. Przeprowadzone badania poziomu lęków u Polaków wykazały, że najciężej kwarantannę społeczną przeszli młodzi ludzie w wieku 18-24 lat. Lęk i nastroje depresyjne były u nich wywołane zmianą trybu życia, koniecznością izolacji i brakiem kontaktu z rówieśnikami. W raporcie zwraca się uwagę, że badaniami objęto tylko osoby korzystające $\mathrm{z}$ Internetu. Fakt ten może mieć, w mojej opinii, istotne znaczenie dla uzyskanych wyników (Gambin i in. 2020).

25 Archiwum autorki.

26 Serwis Rzeczypospolitej Polskiej, https://www.gov.pl/web/koronawirus/zaslon-usta-inos (dostęp: 10.05.2020). 
sąsiadów ${ }^{27}$. Maseczki były „produkowane” chałupniczo z dostępnych materiałów, które nadawały się do tych celów. Internet wypełnił się instrukcjami, jak łatwo i szybko uszyć maseczkę, jakich tworzyw najlepiej do ich wyrobu używać, a także z czego je robić, gdy nie dysponujemy „standardowymi” materiałami. Akcje te miały charakter lokalny i często były inicjowane przez jedną lub dwie osoby. Podjęte przez nie działania stymulowały innych do współuczestnictwa. W wielu przypadkach - zwłaszcza w mniejszych miejscowościach - szycie maseczek było inicjowane przez członkinie kół gospodyń wiejskich lub przedstawicieli lokalnych organizacji kulturalno-społecznych, także rady sołeckie czy władze samorządowe ${ }^{28}$.

\section{2. „Pierwsza linia walki z COVID-19” i działania pomocowe}

Druga grupa, do której skierowane były działania pomocowe, to przedstawiciele wszelkich służb, które znalazły się - jak powszechnie zaczęto mówić - „na pierwszej linii pola walki z COVID-19". Byli to lekarze, pielęgniarki, sanitariusze i inne osoby zatrudnione przede wszystkim w tzw. szpitalach jednoimiennych ${ }^{29}$. Na samym początku wsparcie polegało na poszukiwaniu wyposażenia w środki ochrony osobistej dla osób najbardziej narażonych na zakażenie. Pojawiające się informacje o gwałtownym wzroście zapotrzebowania na te środki i o topniejących ich zapasach przyczyniły się do działań, których celem była wspomniana wcześniej chałupnicza produkcja maseczek i przyłbic. Szycie maseczek mogło być realizowane praktycznie przez każdą osobę dysponującą maszyną krawiecką ${ }^{30}$. Jednakże osoby mające bezpośredni kontakt $\mathrm{z}$ chorymi lub przebywającymi w strefie zagrożenia wymagały zaopatrzenia w specjalne, certyfikowane produkty zabezpie-

27 Na przykład: https://jastrzebiezdroj.naszemiasto.pl/koronawirus-w-jastrzebiu-zdroju-jak-dobry-duszek-za-darmo/ar/c1-7644697 (dostęp: 30.04.2020); http://www.bielsko.biala.pl/aktualnosci/42823/czuje-zal-do-prezydenta-klimaszewskiego-materialu-na-maseczki-wciaz-brakuje (dostęp: 30.04.2020); https://24kurier.pl/koronawirus/szyja-maseczki-i-pomagaja-sasiadom-z-os-zawadzkiego-klonowica-w-szczecinie/ (dostęp: 30.04.2020).

${ }_{28} \mathrm{Na}$ przykład: https://krakow.tvp.pl/47594831/mieszkancy-skawiny-uszyja-maseczki-dlaswoich-sasiadow (dostęp: 30.04.2020); https://sandomierz.gosc.pl/doc/6264055.Gorzyce-Szyjamaseczki-dla-sasiadow (dostęp: 30.04.2020); https://dlugolekainfo.pl/2020/04/23/panie-z-dobroszowa-szyja-maseczki-dla-sasiadow/ (dostęp: 30.04.2020).

29 12.03.2020 poinformowano o przekształceniu 19 placówek medycznych na terenie całej Polski w szpitale zakaźne, nazwane jednoimiennymi. Ich zadaniem było zajmowanie się tylko osobami podejrzanymi o zakażenie wirusem SARS-CoV-2, https://www.gov.pl/web/zdrowie/oddzis-wprowadzimy-stan-zagrozenia-epidemicznego2 (dostęp: 12.03.2020).

30 Jeden z wielu przykładów: https://kielce.naszemiasto.pl/kielce-szyja-maski-dla-medykow-2tysiace-ludzi-wlaczylo-sie/ar/c1-7629237 (dostęp: 30.04.2020). 
czające. W tej sytuacji szyte chałupniczo maseczki mogły pełnić jedynie funkcję wspomagającą w sytuacjach uznawanych za względnie bezpieczne.

Nieco inaczej przedstawiała się sytuacja $\mathrm{z}$ wyrobem przyłbic, który wymagał już bardziej zaawansowanej wiedzy i odpowiedniego sprzętu. Zaistniałe warunki zaowocowały spontaniczną i nieformalną (organizowaną ad hoc) współpracą instytucji, głównie o profilu technicznym ${ }^{31}$, oraz placówek medycznych. Zarówno pracownicy naukowi, jak i studenci rozpoczęli produkcję przyłbic, a w miarę zdobywania doświadczenia modyfikowali je, wprowadzając coraz doskonalsze zabezpieczenia. Wraz z rozwojem epidemii i zyskiwaniem wiedzy o możliwych polach wsparcia w zakresie prowadzonej zaawansowanej diagnostyki, a także coraz lepszego poznawania wirusa wywołującego COVID-19 wspomniana pomoc przechodziła w działania bardziej profesjonalne. Przekazywano więc np. sprzęt wykorzystywany w normalnych sytuacjach do innych celów, a w zaistniałych warunkach dostosowywany do nowych potrzeb i udostępniany placówkom medycznym $^{32}$.

Pomoc tej grupie, polegająca na zaopatrzeniu w środki ochrony osobistej, ze względu na wymóg profesjonalnego certyfikowanego sprzętu, tylko w niewielkim stopniu mogła być realizowana przez pojedyncze osoby metodą chałupniczą. Najbardziej efektywną formą udzielanego wsparcia stanowiły przedsięwzięcia, których celem było zbieranie środków na zakup koniecznego wyposażenia. Nie wyczerpując listy podejmowanych w tym czasie działań, pragnę zwrócić uwagę na kilka, które umożliwiały udział zarówno pojedynczym osobom, jak i przedsiębiorcom, a także przedstawicielom firm. Akcje te dawały równe (nie w znaczeniu materialnym) uczestnictwo wszystkim osobom, które uznały to za słuszne.

31 Pierwsze informacje o wyrobie przyłbic przez pracowników Politechniki Krakowskiej podano 29.03.2020 r., https://krakow.naszemiasto.pl/krakow-politechnika-krakowska-wspierabohaterskich-lekarzy/ar/c1-7625237 (dostęp: 10.04.2020), a także https://cowkrakowie.pl/2020/04/ spolecznosc-politechniki-krakowskiej-pomaga-medykom/ (dostęp: 10.04.2020). Podobną akcję prowadzono na krakowskiej Akademii Górniczo-Hutniczej. Jej rezultat to 20 tysięcy przyłbic przekazanych do różnych placówek medycznych Polski południowej: https://zdrowie.wprost. pl/koronawirus/10324428/krakow-ponad-20-tys-przylbic-medycznych-powstalo-w-agh.html (dostęp: 15.05.2020), a także https://www.krakow.pl/aktualnosci/238691,29,komunikat,studenci_ agh_drukuja_przylbice_dla_lekarzy.html (dostęp: 30.04.2020).

32 Przykładem może być użyczenie kamer termowizyjnych przez Politechnikę Krakowską Krakowskiemu Szpitalowi Specjalistycznemu im. Jana Pawła II, https://www.pk.edu.pl/index. php?option=com_content\&view=article\&id=3387:specjalne-kamery-z-politechniki-krakowskiejw-szpitalu-im-jana-pawla-ii-w-krakowie\&catid=49\&lang=pl\&Itemid=944 (dostęp: 24.05.2020) czy też udostępnienie „superkomputera” przez Akademię Górniczo-Hutniczą, https://www. agh.edu.pl/nauka/info/article/superkomputer-prometheus-wspomaga-naukowcow-w-walce-zkoronawirusem/ (dostęp: 24.05.2020). Podane przykłady są jedynie cząstką działań podejmowanych $\mathrm{w}$ tym czasie przez różne środowiska badawcze. Wpisanie do przeglądarki Google hasła „naukowcy w walce z COVID-19" daje wynik około 3,1 miliona rekordów, tylko na stronach polskojęzycznych (na dzień 24.05.2020). 
Już 3 marca została uruchomiona za pośrednictwem Fundacji SiePomaga zbiórka pod hasłem „Wspieramy polską służbę zdrowia w czasie walki z epidemią COVID-19"33. Do akcji przystąpiła również Wielka Orkiestra Świątecznej Pomocy, która organizowała m.in. transporty specjalistycznego sprzętu ochronnego dla służby zdrowia ${ }^{34}$. Caritas już w marcu uruchomiła akcję „Wdzięczni Medykom”35. Warto także wspomnieć o akcji „Hot16challenge” zainicjowanej przez polskiego rapera Solara ${ }^{36}$, pierwotnie skierowanej do środowiska muzyków hip-hopu ${ }^{37}$. Głównym jej celem była aktywacja jak największej liczby artystów i ich fanów, co miało przełożyć się na udział $\mathrm{w}$ akcji zbierania funduszy - jak pierwotnie zakładano $1 \mathrm{mln} \mathrm{z}^{38}$ - aby przeznaczyć je na pomoc lekarzom i szpitalom w walce z COVID-19. Inicjatywa bardzo szybko wyszła poza zakrojone ramy, obejmując także środowiska muzyków nierapujących oraz polityków. W przedsięwzięciu wziął udział m.in. prezydent Andrzej Duda, a także inne osoby, w tym ku zaskoczeniu - klerycy z Wyższego Seminarium Duchownego Diecezji Ełckiej $^{39}$. Jedna $\mathrm{z}$ osób obserwujących wydarzenie, o pseudonimie Jacob Parkour, stwierdziła:

I chyba nikt [...] nie spodziewał się, że akcja pójdzie DOSŁOWNIE na całą Polskę, a po niespełna dwóch tygodniach swoją hot16 nagra prezydent Andrzej Duda, Janusz Korwin-Mikke i wiele, wiele innych znanych postaci, choć niemających nic wspólnego ze środowiskiem hiphopowym. Nie wiem, czy tak miało być, chyba niekoniecznie, ale przynajmniej jest śmiesznie i nie mam wątpliwości, że to zapisze się $\mathrm{w}$ historii ${ }^{40}$.

Przedsięwzięć, których celem było wsparcie służby zdrowia przez osoby indywidualne, a także fundacje czy przedsiębiorstwa, było doprawdy dużo. Za podanymi powyżej przykładowymi działaniami kryją się uczestnictwo i finansowe

${ }_{33} 30.08 .2029$ r. licznik uczestników zbiórki wskazywał 525099 osób, a zebrana kwota wynosiła 30086 253,00 zł, cf. „SiePomaga” na walkę z COVID-19, https://www.siepomaga.pl/koronawirus (dostęp: 30.08.2020).

34 WOŚP, https://newsroom.wosp.org.pl/97175-kolejne-kombinezony-dla-medykowwalczacych-z-covid-19 (dostęp: 30.08.2020).

35 Caritas, „Wdzięczni Medykom”, https://caritas.pl/medycy (dostęp: 30.08.2020).

36 Solar o Hot16challenge, https://noizz.pl/muzyka/solar-opowiada-o-hot16challenge2rapujacych-celebrytach-i-andrzeju-dudzie/rp6v8vf (dostęp 25.05.2020), a także: https://www. youtube.com/watch?v=fG3Mzg3bkgs (dostęp: 25.05.2020).

37 Polega ona na nagraniu i opublikowaniu on-line wiersza składającego się z 16 wersów, a następnie nominowaniu czterech artystów do wykonania swoich utworów w ciągu 72 godzin.

3830.08 .2020 r. w przedsięwzięciu odnotowano udział 4183 artystów i zebrano 3680 852,88 zł. Zbiórka była organizowana przy udziale (zebrana kwota jest przekazywana) Fundacji SiePomaga, $c f$. oficjalna strona „Hot16challene”, https://hot16challenge.network/pl (dostęp: 30.08.2020).

39 Zarejestrowany udział kleryków z Wyższego Seminarium Duchownego w Diecezji Ełckiej, https://www.youtube.com/watch?v=Rq_U3hVI3Bc (dostęp: 29.05.2020).

40 Wypowiedź na forum, https://www.youtube.com/watch?v=fG3Mzg3bkgs (dostęp: 29.05.2020). 
wsparcie różnych firm, zarówno tych o zasięgu krajowym, ponadnarodowym, jak i lokalnym ${ }^{41}$, a także uczestnictwo indywidualnych osób.

\section{W kierunku konkluzji}

Mimo że piszę te słowa jeszcze w trakcie trwania stanu epidemii, to w mojej opinii już teraz można dostrzec etapowość procesu, przez który wciąż jeszcze przechodzimy. Do pewnego stopnia odzwierciedla się on w sposobie udzielania wsparcia potrzebującym, a także w zaangażowaniu w działania pomocowe.

$\mathrm{Na}$ samym początku epidemii niewydolność instytucji (braki kadrowe, zamknięcie biur, przejście w tryb pracy zdalnej, dezorganizacja), dla których zadania pomocowe są podstawową działalnością, wywołała spontaniczne, społeczne działania oddolne. Ten etap najpełniej ujawnił aktywność lokalnej społeczności, przejawiającą się w organizowaniu, uczestniczeniu lub pośredniczeniu w pomocy, kierowanej najczęściej do członków własnej społeczności.

Kolejnym etapem było przejmowanie i koordynowanie działań pomocowych przez przedstawicieli władz. Także i w tym czasie nie zrezygnowano z pomocy osób postronnych, niezwiązanych z instytucjami pomocowymi. Jednakże aktywność „zwykłych” ludzi maleje.

Etapowość, o której wspomniałam, była obserwowana również przez badaczy społeczności doświadczonych klęskami żywiołowymi na przełomie XX i XXI w. (Sitek 1997; Sołdra-Gwiżdż 1998; Nycz 1998; Hajduk-Nijakowska 1999, 2005; Baniowska-Kopacz 2013, 2017). Pierwsza faza tych wydarzeń obejmowała zachwianie się panującego dotąd porządku, a w konsekwencji powstanie w sposób „naturalny” nowego porządku, tzw. ładu wspólnoty. Było to związane $\mathrm{z}$ bezradnością lokalnych władz i niewywiązywaniem się z powierzonych im zadań, co spowodowało przejęcie inicjatywy przez małe grupy ludzi. $Z$ chwilą podjęcia prób przywrócenia porządku i na powrót przejęcia władzy przez organy do tego powołane następuje rozpad ładu z czasu kataklizmu (Hajduk-Nijakowska 1999: 399-400; Hajduk-Nijakowska 2005: 92; Kaniasty 2003: 90, 224-225; Sołdra-Gwiżdż 1998: 31).

Przez cały czas „zamknięcia” podejmowane były przedsięwzięcia, które przybierały postać społecznego pospolitego ruszenia. Charakterystyczne było pojawianie się lokalnych „ognisk”, skupiających ludzi inicjujących działania i następnie włączanie się w nie coraz to nowych osób. Ogniska takie powstawały niezależnie w różnych miejscach Polski. Były rozsadnikami różnych aktywności istniejących poza strukturami oficjalnych strategii „walki z COVID-19”. Taki charakter miały: szycie maseczek, produkcja przyłbic i zbieranie funduszy na zakup koniecznego

${ }^{41}$ Celowo ich tutaj nie wymieniam, natomiast informacje o uczestnikach zbiórki w większości przypadków można znaleźć na oficjalnych stronach organizatorów poszczególnych akcji. 
wyposażenia medycznego do walki z COVID-19. Tym, co różni działania ukierunkowane na pomoc wyróżnionej grupie pierwszej i drugiej, jest stopień anonimowości osób, do których pomoc była kierowana. W przypadku grupy pierwszej zawsze na jakimś etapie działań pojawiały się osoby, które znały odbiorców pomocy. Zaobserwowane $\mathrm{w}$ tych przypadkach sposoby udzielanego wsparcia uznaję za najbliższe formom występującym w przeszłości, które przez badaczy zaliczane są do działań pomocowych w sytuacjach wyjątkowych, burzących rutynę dnia codziennego (Zawistowicz-Adamska 1950/1951). Zasada wzajemności wyrażona słowami do ut des sprawiała, że nikt z członków tzw. społeczności tradycyjnej nie mógł się jej przeciwstawić, nie narażając się na utratę prawa do korzystania z pomocy w razie potrzeby (Zawistowicz-Adamska 1950/1951: 26). W sytuacjach podobnych do tych, jakie obserwujemy obecnie, stawała się ona swoistym rodzajem wzajemnego ubezpieczenia, zawieszonego w czasie do chwili, kiedy udzielający pomocy/wsparcia w określonym momencie sam będzie go potrzebował ${ }^{42}$. $\mathrm{Z}$ zebranych informacji wynika, iż także współcześnie podejmowanym działaniom towarzyszyła nadzieja, że okazane wsparcie zostanie odwzajemnione, jeśli zaistniałaby taka potrzeba ${ }^{43}$.

W przypadku działań na rzecz osób zaliczonych do drugiej grupy ich cechę stanowiło to, że nie były kierowane do konkretnej osoby znanej z imienia i nazwiska. W tym przypadku jednostki współdziałające, ale jednak działające indywidualnie, pracowały dla dobra wszystkich. Ich współpracy towarzyszyło przeświadczenie, że dokładając nawet niewielką część własnych starań, przyczyniają się do ochrony nas wszystkich przed COVID-19. Ten rodzaj współdziałania jest najbliższy formom określanym jako działania dla wspólnego dobra. Maria Biernacka, pisząc o działaniach podejmowanych w takich sytuacjach, zaznaczała, że współdziałające w gromadzie jednostki pracują dla wszystkich, a zarazem dla siebie (1962: 16). Zapewne także i we współczesnych działaniach z czasu pandemii można by dopatrzeć się dążenia do zabezpieczenia siebie, swoich bliskich poprzez troskę o tych, którzy mogą nas ratować z kłopotów zdrowotnych w przyszłości. Zacytowana autorka dodawała też, że udział w takiej działalności wymaga od jej inicjatorów i wykonawców zarówno solidarności, jak i świadomości celów oraz wartości szerszych - ponadindywidualnych i ponadrodzinnych (Biernacka 1962: 16). Wymaga to dojrzałości społecznej, poczucia wspólnoty i świadomości współzależności w życiu społecznym.

Jak już zaznaczałam, pomoc w postaci działań oddolnych, spontanicznych, skupiających wokół siebie różnych ludzi, łączących się wokół określonych celów (bez względu na to, kim są/byli „wcześniej”), najintensywniej była realizowana w czasie „zamknięcia”. Długi czas trwania izolacji społecznej, narastająca frus-

42 Cf. Koncepcja „odroczonej wdzięczności” (Blau 1992: 265).

43 Archiwum autorki. 
tracja wywołana już nie tylko lękiem przed COVID-19, lecz także obawami np. utraty źródeł utrzymania zachwiała tą spontanicznie powstałą solidarnością. Czas ten zbiega się z wdrożoną już instytucjonalną pomocą, realizowaną przez organy do tego powołane, a także z łagodzeniem ograniczeń ${ }^{44}$. Za symptomatyczny można uznać udział indywidualnych osób i zebranych środków w okresie do 30 maja, kiedy rozpoczęto IV etap „luzowania”, i 30 sierpnia, w dwóch spośród przywołanych wcześniej akcjach pomocy - „SiePomaga” i „Hot16challenge”45. Wyniki obserwacji prezentuję w tabeli 1 .

Tabela 1. Aktywność w działaniach pomocowych

\begin{tabular}{|l|r|r|r|r|}
\hline \multirow{2}{*}{} & \multicolumn{2}{|c|}{ SiePomaga } & \multicolumn{2}{c|}{ Hot16Challenge } \\
\cline { 2 - 5 } & $\begin{array}{c}\text { Liczba } \\
\text { uczestników } \\
\text { zbiórki }\end{array}$ & Zebrana kwota & $\begin{array}{c}\text { Liczba artystów } \\
\text { biorących udział }\end{array}$ & Zebrana kwota \\
\hline 30.05 .2020 & 485335 & $28765251,90 \mathrm{z \nmid}$ & 4093 & $3439984,00 \mathrm{zł}$ \\
\hline 30.08 .2020 & 525099 & $30086253,00 \mathrm{zł}$ & 4183 & $3680852,88 \mathrm{zł}$ \\
\hline
\end{tabular}

Źródło: opracowanie własne

W okresie od 30 maja do 30 sierpnia w ramach akcji zorganizowanej przez fundację „SiePomaga” przybyło 39764 uczestników zbiórki, co stanowi 7,57\% wszystkich uczestników zarejestrowanych 30 sierpnia. W przypadku „Hot16Challenge" w tym samym czasie przybyło 90 artystów-uczestników przedsięwzięcia, to jest 2,15\% wszystkich artystów zarejestrowanych na dzień 30 sierpnia 2020 r. Zebrana kwota w omawianym czasie wzrosła w pierwszym przypadku o 1321 001,10 zł, co stanowi w przybliżeniu 4,39\% całej zebranej kwoty wykazanej 30 sierpnia. W drugim przypadku wzrost zbiórki wyniósł 240 868,88 zł, co stanowi w przybliżeniu 6,54\% całej kwoty wykazanej 30 sierpnia. Jak widać, w obydwu przypadkach szczyt aktywności pomocowej przypadł na czas „zamknięcia”. Impet działań pomocowych zdecydowanie zmalał w czasie po ogłoszeniu przez władze powrotu do „nowej normalności”. Niewątpliwie wpływ na aktywność (po 30 maja) w omawianej sferze życia społecznego miały także: zachowanie polityków ignorujących ustanowione zasady postępowania w czasie epidemii ${ }^{46}$, narastająca

44 Zmniejszanie ograniczeń w Polsce rozpoczęło się od 20.04.2020 r. i zostało zaplanowane na 4 etapy: https://www.gov.pl/web/koronawirus/nowa-normalnosc-etapy (dostęp: 25.08.2020). Drugi etap rozpoczął się 04.05.2020, trzeci od 25.05.2020, czwarty od 30.05.2020.

45 Dane liczbowe prezentowane w tabeli 1 były dostępne na oficjalnych stronach obydwu zbiórek w poszczególnych dniach. Niestety, historia przebiegu zbiórki nie jest dostępna on-line. Publikowane są jedynie aktualne dane, a zegar poszczególnych liczników cały czas się przesuwa.

46 Arogancję władzy, niestosowanie się przedstawicieli władz do uchwalonych przez siebie i obowiązujących przepisów prawa doskonale wyraził Kazimierz Staszewski „Kazik” w swoim 
frustracja zaistniałą sytuacją, a także zbliżające się miesiące letniego odpoczynku. Myślę jednak, że spadek aktywności pomocowej sygnalizuje wejście epidemii w kolejny etap pod względem społecznym ${ }^{47}$. Znamienne tutaj jest określenie pojawiające się zarówno w wypowiedziach rządzących, jak i komentatorów bieżących wydarzeń: „nowa normalność” 48 . Bynajmniej nie chodzi o sytuację po ustaniu pandemii, bowiem cały czas jesteśmy w trakcie jej trwania. „Nowa normalność” dotyczy życia społecznego, gospodarczego, kulturalnego w czasie pandemii, jednakże po zniesieniu części ograniczeń wprowadzonych w czasie „zamknięcia”.

Wiele spośród zaobserwowanych zjawisk skłania do przywołania kategorii Victora Turnera - liminalności i communitas (Turner 2010). Liminalność jest stanem, ale też procesem, który plasuje się "pomiędzy”. Nie należy ani do tego, co było wcześniej, ani do tego, co ma nastąpić. Określenie „nowa normalność, czyli normalność czasu pandemii z poluzowanymi nieco ograniczeniami okresu „zamknięcia”, jest takim stanem pomiędzy. Nie jest ani tym, co było przed, ani najprawdopodobniej nie jest tym, co ma nastąpić ${ }^{49}$. „Atrybuty liminalności lub liminalnych personae («ludzi progu») są z konieczności ambiwalentne, ponieważ owe warunki i osoby wymykają się sieci klasyfikacyjnej, która zwykle wyznacza miejsce stanom i pozycjom w przestrzeni kulturowej” (Turner 2010: 114). Communitas - jak mówi cytowany autor - pojawia się „w okresie liminalnym, jest modelem społeczeństwa pozbawionego struktury lub ze strukturą szczątkową i ze stosunkowo niezróżnicowanym comitatus, wspólnotą, a nawet komunią równych jednostek" (Turner 2010: 117). W innym miejscu Turner zaznacza, że:

Communitas albo „społeczeństwo otwarte” tym się właśnie różni od struktury albo „społeczeństwa zamkniętego", że potencjalnie lub idealnie może się rozciągnąć do granic człowieczeństwa. W praktyce [...] początkowy rozmach szybko ulega wyczerpaniu i „ruch” staje się instytucją wśród innych instytucji [...] Są to zasadniczo fenomeny stanów przejściowych (Turner 2010: 128-129).

utworze, zatytułowanym Twój ból jest lepszy niż mój, https://www.youtube.com/watch?v= o9LzNtpjhV0 (dostęp: 25.08.2020).

47 Sygnalizują go także inne zjawiska obserwowane w czasie letnich miesięcy. Wśród nich wymienić można zyskującą na popularności polaryzację poglądów na sytuację wywołaną przez wirusa SARS-CoV-2, które kryją się za terminami: Covidiot, https:/www.health.com/condition/infectious-diseases/coronavirus/what-does-covidiot-mean (dostęp: 20.08.2020) i Covidianie, https:// jarek-kefir.com/2020/06/24/covidianie-niebezpieczna-sekta-czczaca-koronawirusa/ (dostęp: 20.08. 2020). W tym nurcie pozostają także np. obserwowane sposoby spędzania wakacji, których symbolem w Polsce stała się plaża we Władysławowie: https://businessinsider.com.pl/wiadomosci/epidemia-koronawirusa-imprezy-masowe-zdjecia/8p4v88g (dostęp: 30.08.2020).

48 Termin ten jest także wykorzystany na oficjalnych stronach www Rządu RP w dokumencie prezentującym etapy znoszenia ograniczeń, wprowadzonych w czasie „zamknięcia” (lockdown).

49 Jest pewna szansa, że stan obecny pozostanie z nami już na zawsze, przynajmniej jeśli chodzi o ochronę epidemiologiczną. 
Cechą Communitas jest spontaniczność, bezpośredniość, solidarność, a także jego zakotwiczenie w teraźniejszości i krótkotrwałość. Obydwie przywołane kategorie doskonale opisują dziejącą się rzeczywistość czasu pandemii.

Kończąc, pragnę przypomnieć najważniejsze obserwacje poczynione w kontekście podejmowanych działań pomocowych. Cechą charakterystyczną pomocy czasu pandemii jest inicjowanie, a często pełna realizacja (jak np. zbieranie funduszy) działań pomocowych w wirtualnym świecie. Czas pandemii rozmył jasność kategorii najbardziej poszkodowanych czy najbardziej potrzebujących pomocy w dziejących się zdarzeniach. Grupy adresatów pomocy można by określić empatycznymi, a wybory osób, którym pomagano, wynikały ze współodczuwania i współprzeżywania sytuacji, w jakiej się one znalazły. Inną cechą obserwowanych zdarzeń jest etapowość, która była także opisywana w sytuacjach klęsk żywiołowych. Elementami owej etapowości jest spontaniczne powstawanie lokalnych wspólnot, podejmujących akcje pomocowe. Ogniska pomocowe powstawały niezależnie, w różnych miejscach Polski. Stawały się rozsadnikami rozmaitych aktywności istniejącymi poza strukturami oficjalnych strategii „walki z COVID-19”. Przywracanie przez władze stanu „nowej normalności” i przejmowanie działań pomocowych przez instytucje do tego powołane spowolniło, osłabiło udział zwykłych ludzi w organizowaniu spontanicznych działań. Przeżywany czas ma cechy Turnerowskiej liminalności, a wspólnoty pomocowe można opisać terminem communitas.

\section{Bibliografia}

Aronson E., Wilson T.D., Akert R.M.

1997 Zachowanie prospołeczne: dlaczego ludzie pomagaja innym, w: tychże, Psychologia społeczna. Serce i umyst, Poznań, s. 397-431.

Baniowska-Kopacz E.

2013 „From pestilence, famine, fire...” - rural communities and elementary disasters, „Ethnologia Polona”, t. 33-34, s. 165-183.

Baniowska-Kopacz E.

2017 Społeczność lokalna i trauma klęski elementarnej, w: Národy - Mésta - Lidé Traumata, red. B. Soukupová, R. Godula-Węcławowicz, „Urbánní Studie”, t. 12, Praha, s. 97-104.

Batorski D., Olcoń-Kubicka M.

2006 Prowadzenie badań przez Internet - podstawowe zagadnienia metodologiczne, „Studia Socjologiczne”, t. 3 (182), s. 99-132.

Biernacka M.

1962 Potakówka wieś powiatu jasielskiego (1890-1960). Z badań nad współdziałaniem gospodarczym, Warszawa. 
Blau P.M.

1992 Wymiana jako podstawowa siła życia społecznego, w: Współczesne teorie wymiany społecznej. Zbiór tekstów, red. M. Kempny, J. Szmatka, Warszawa.

Gambin M., Sękowski M., Woźniak-Prus M., Cudo A., Hansen K., Gorgol J., Huflejt-Łukasik M., Kmita G., Kubicka K., Łyś A.E., Maison D., Oleksy T., Wnuk A.

2020 Uwarunkowania objawów depresji i lęku uogólnionego u dorostych Polaków $w$ trakcie epidemii Covid-19 - raport z pierwszej fali badania podłużnego, http://psych. uw.edu.pl/wp-content/uploads/sites/98/2020/05/Uwarunkowania_objawow_depresji_leku_w_trakcie_pandemii_raport.pdf (dostęp: 25.06.2020).

Gouldner A.

1992 Norma wzajemności. Preliminaria, w: Współczesne teorie wymiany społecznej. Zbiór tekstów, red. M. Kempny, J. Szmatka, Warszawa.

Hajduk-Nijakowska J.

1999 Sytuacja komunikacyjna $w$ stanie zagrożenia, w: Folklorystyczne $i$ antropologiczne opisanie świata. Księga ofiarowana Profesor Dorocie Simonides, red. T. Smolińska, Opole, s. 395-407.

Hajduk-Nijakowska J.

2005 Żywioł i kultura. Folklorystyczne mechanizmy oswajania traumy, Opole.

Jemielniak D.

2013 Netnografia, czyli etnografia wirtualna - nowa forma badań etnograficznych, „Prakseologia”, nr 154, s. 97-116.

Kaniasty K.

2003, Klęska żywiołowa czy katastrofa społeczna? Psychospołeczne konsekwencje polskiej powodzi 1997 roku, Gdańsk.

Lévi-Strauss C.

1970, Antropologia strukturalna, przeł. K. Pomian, Warszawa.

Lévi-Strauss C.

1973 Wprowadzenie do twórczości Marcela Maussa, w: M. Mauss, Socjologia i antropologia, przeł. M. Król, K. Pomian, J. Szacki, Warszawa, s. XI-LVIII.

Malinowski B.

1967 Argonauci Zachodniego Pacyfiku. Relacje o poczynaniach i przygodach krajowców $z$ Nowej Gwinei, przeł. B. Olszewska-Dyoniziak, S. Szynkiewicz, Warszawa.

Malinowski B.

1984 Zwyczaj i zbrodnia w społeczności dzikich, przeł. J. Chałasiński, A. Waligórski, Warszawa.

Mauss M.

1973 Socjologia i antropologia, przeł. M. Król, K. Pomian, J. Szacki, Warszawa.

Nycz E. (red.)

1998 Społeczności lokalne w sytuacji zagrożenia i kataklizmu. Materiały z III Kędzierzyńsko-Kozielskiego Seminarium Naukowego „Społeczeństwo wobec sytuacji zagrożenia i kataklizmu”, Opole-Kędzierzyn-Koźle.

Pomieciński A.

2012 E-humanitaryzm: pomaganie przez klikanie, „Kultura Popularna”, nr 3 (33), s. 86-95.

Sahlins M.D.

1992 Socjologia wymiany w społeczeństwach pierwotnych, w: Współczesne teorie wymiany społecznej. Zbiór tekstów, red. M. Kempny, J. Szmatka, Warszawa. 
Sitek W.

1997 Wspólnota i zagrożenie: wrocławianie wobec wielkiej powodzi : socjologiczny przyczynek do analizy krótkotrwałej wspólnoty, Wrocław.

Sołdra-Gwiżdż T. (red.)

1998 Społeczne skutki powodzi w lipcu 1997 roku w województwie opolskim, „Zeszyty Odrzańskie. Seria Nowa”, nr 17.

Sztompka P.

2000 Trauma wielkiej zmiany. Społeczne koszty transformacji, Warszawa.

Turner V.

2010 Proces rytualny. Struktura i antystruktura, przeł. E. Dżurak, Warszawa.

Zawistowicz-Adamska K.

1950/1951 Pomoc wzajemna i współdziałanie w kulturach ludowych, „Prace i Materiały Etnograficzne", nr 8-9, s. 1-154. 